\title{
Bert Hellinger ve Aile Dizimi Terapisi
}

\author{
Nesrin DUMAN ${ }^{1}$
}

\begin{abstract}
Özet: Bu çalışmanın amacı Alman psikoterapist Bert Hellinger'ı ve aile dizimi terapisini tanıtmayı, modeldeki bazı önemli kavramları, soruna yol açan nedenleri ve duyguların modeldeki yerini açıklamaktır. Bu amaçla bazı elektronik veri tabanları (Google Akademik, EBSCO host, Elektronik Kitaplar, Wiley Online Library) taranmıştır. 20. yy'ın sonlarında Hellinger tarafından dünyaya tanıtılmış olan aile dizimi terapisi, ailenin nesiller boyu birbirlerine görünmez bağlarla bağlı olduğu anlayışını benimsemektedir. Bireyi, içinde doğduğu ailenin şekillendirdiğine inanan bu yaklaşım, aile sistemindeki bir kişinin kadersel olarak diğer bir aile üyesine bağlı olduğunu ileri sürmektedir. Hellinger modelini oluştururken, Arthur Janov, Eric Berne, Milton Erikson ve Ivan Boszormenyi-Nagy gibi isimlerden ve terapi yaklaşımlarından da faydalanmıştır. Aile dizimi bu haliyle çeşitli terapi akımlarının sentezlenmesiyle ve Zulu kültür ve ritüellerinin birleştirilmesiyle geliştirilmiş bir terapi modelidir. Aile dizimi modelinde psikolojik rahatsızlıkların önemli bir kısmına, hatta belki de çoğunluğuna kök ailede yaşanmış sorunların sebep olduğunu ileri sürülmektedir. Bireysel ve grup dizimi şeklinde uygulanabilen aile diziminde, sıranın/düzenin bozulması, sistemik karmaşa, kesintiye uğramış erişim/yönelim çabaları sebebiyle ortaya çıkan sorunlar ele alınmaktadır. Psikoterapi seansı sırasında birey ailesine geri götürülüp, ailesiyle içsel dünyada barıştırılmaktadır. Kişiye aile sistemi içinde mevcut yeri gösterilmekte, bireyin ailede özdeşleştiği kişinin farkına varması ve bu özdeşimi çözüme kavuşturması için firsat sunulmakta, sistemin bozulan yanları onarılmaya çalışılmaktadır. Bu haliyle aile içindeki enerjinin özgürce akması sağlanmaktadır.
\end{abstract}

Anahtar sözcükler: Aile Dizimi, Bert Hellinger, Terapi.

\section{Bert Hellinger and Family Constellation Therapy}

\begin{abstract}
The aim of this study is to introduce the German psychotherapist Bert Hellinger and the family constellation therapy, to explain some important concepts in the model, the causes of the problem and the place of emotions. For this purpose, some electronic databases (Google Scholar, EBSCOhost, Electronic Books, Wiley Online Library) were scanned. Family constellation therapy, introduced to the world by Hellinger at the end of the $20^{\text {th }}$ century, adopts the understanding that the family has been connected invisibly to each other for generations. This approach, which believes that family in which the individual was born shapes the person and all members in the family system is destinedly connected to each other. While creating his model, Hellinger also benefited from some important names and therapy approaches such as Arthur Janov, Eric Berne, Milton Erikson and Ivan Boszormenyi-Nagy. The family constellation is a therapy model developed by synthesizing various therapy approaches and combining Zulu culture and rituals. It is suggested in the model that a significant part of the psychological disorders, perhaps even the majority, were caused by problems in the root family. In the family constallation, which can be applied as individual and group session, problems arising due to disruption of order, systemic entanglement, interrupted reaching-out movement are discussed. During the psychotherapy session, the individual is taken back to his family, reunited with his/her family in the inner world. It is shown his current place in the family system. An opportunity is given to the individual to recognize the person whom he/she has identified in the family and to solve this identification. Thus, the energy in the family is freely flowed.
\end{abstract}

Key words: Family Constellation, Bert Hellinger, Therapy.

${ }^{1}$ Dr., İstanbul Ayvansaray Üniversitesi Psikoloji Bölümü, Orcid İd: https://orcid.org/0000-0002-2751-8315

Address of correspondence/Yazışma adresi: Yrd. Doç. Dr. Nesrin Duman. İstanbul Ayvansaray Üniversitesi, Psikoloji Bölümü. E-mail: nesrinduman@windowslive.com

Date of Received/Geliş Tarihi: 29.05.2020, Date of Revision/Düzeltme Tarihi: 23.06.2020, Date of Acceptance/Kabul Tarihi: 12.07 .2020

Citing/ Referans Gösterimi: Duman, N. (2020). Bert Hellinger ve Aile Dizimi TerapisiKıbrıs Türk Psikiyatri ve Psikoloji

Dergisi, 2(2): 114-9 doi:10.35365/ctjpp.20.02.16 


\section{Giriş}

Aile, her birey için temeldir ("The Original Hellinger", 2020). Bebeğin dünyaya geldiği aile, tam bir aile olmayabileceği gibi, zaman içerisinde de eksilebilmektedir. Anne, baba ve varsa kardeş(ler) ölüm, boşanma veya farklı ayrılık biçimleriyle kaybedilebilmektedir. Buna ek olarak, çeşitli nedenlerle çocuğun bakımı farklı bir kişi tarafından yapılıyor olabilmektedir. Böyle bir durumda bakım veren kişi çocuğun psikolojik ebeveyni olabilmekte ve çocuğun gelecek yaşamında büyük bir etkiye sahip olabilmektedir (Toman, 1993). Yapılan çalışmalar (örneğin Bowlby, 1951; Toman, 1961) göstermektedir ki değişen aile durumları bireyin hem aile içindeki hem de aile dışındaki sosyal bağlamda sosyal davranışları üzerine farklı etkiler yaratmaktadır. Totaliter toplumlarda bile, ailenin etkisi, bireylerin gelişimindeki rolünü en aza indirmeye yönelik sistematik girişimlere rağmen devam etmektedir (Laosa ve Sigel, 1982).

Aile terapisi, bir veya birkaç nesli kapsayabilecek tüm aile ile çalışmak olarak kabul edilmektedir. Ailenin etkisi ve karşılıklı ilişkiler göz önüne alındığında bireysel terapi de bu konsepte dahil edilmektedir. Tüm bu yöntemler, ortak olarak sistemik bir bakış açısını paylaşmaktadır. Böylece danışanlar artık bireyler olarak değil, bir bağlam içindeki bileşenler olarak görülmektedir. Sistemik görüş, bireyin bu bağlamda yerleşik olduğunu ve bu bağlamın kurallarına tabi olduğunu vurgulamaktadır. Kişinin eylemleri ve davranışları, duygusal bozuklukları ve psikosomatik hastalıkları artık kesin olarak biyografileri temelinde değil, birey ve sistem arasındaki sürekli etkileşimin sonucu olarak açıklanmaktadır (Franke, 2017). Psikoterapi bağlamında sistem teorileri ve aile dizimi, yaşam öyküsünün gelişimini bozulmaların ve hastalıkların ana kaynağı olarak gören psikolojinin temel ilkesinin çok ötesine geçmektedir (Franke, 2017). Tamamıla özgün bir psikoterapi modeli geliştirmiş olan Hellinger (1995) ciddi duygusal bozuklukların (örn. duygudurum bozuklukları, depresyon vb.), bilinçsiz özdeşleşmeye dayanan nesiller arası sistemik devralmaların sonucu olarak ortaya çıkabileceği hipotezini ortaya koymuştur. Ayrıca alkolizm, madde kötüye kullanımı, intihar, yeme bozuklukları (blumnia ve anoreksia) gibi problemlerin ailedeki bir olay ya da olgu ile bağlantılı olduğunu ileri sürmektedir (Mackay, 2012).

\section{Çalışmanın Amacı}

Bu çalışma Hellinger'ı ve aile dizimi modelini tanıtmayı, modeldeki bazı önemli kavramları, bireyde duygusal soruna yol açan nedenleri ve duyguların modeldeki yerini açıklamayı esas almıştır. Aile dizimi terapisi, son yıllarda özellikle Almanca dilini konuşan ülkelerde dikkatle incelenmeye başlanmıştır. Bu modele ilgi ülkemizdeki terapistlerce de her geçen gün artmaktadır. Ancak literatür incelendiğinde modele dair Türkçe ve İngilizce yayınların oldukça sınırlı olduğu anlaşılmıştır. Buna en temel sebep Hellinger'in yöntemlerine ilişkin kitaplarının, videolarının ve yazılarının büyük çoğunluğunun İngilizce olarak mevcut olmamasidır ("Family Constellations", 2016). Bu nedenle aile dizimi modelinin anlaşılması ve Türkçe literatüre bir yayın kazandırılması amaçlanarak çalışma başlatılmıştır.

\section{Araştırma Stratejisi ve Veri Kaynakları}

Literatür Mart-Haziran 2020 tarihleri arasında arama motorlarında Google Scholar, EBSCOhost, Elektronik Kitaplar, Wiley Online Library veri tabanları taranarak oluşturulmuştur. Tarama yapılırken "Bert Hellinger", "family constellation", "aile dizimi" anahtar kelimeleri kullanılmıştır. Elektronik arama ile ulaşılan yayınlar araştırmacı tarafından gözden geçirilmiştir. Çalışmanın kapsamında kullanılan makale ve kitaplar erişime açık olan arama motoru kullanılarak ve elektronik veri tabanından alındığı için etik izin gerekmemektedir.

\section{Bert Hellinger Kimdir?}

1925 yılında doğmuş olan Hellinger, felsefe, pedagoji ve teoloji eğitimi almış, sonrasında papaz olmuştur. Güney Afrika'da on alt1 yıl boyunca Katolik misyoner olarak görev yapmış, bu dönemde şaman inançlarına bağlı yaşamakta olan Zulu'ları gözlemlemiştir. Zulu kabilesi, Güney Afrika'daki KwaZulu Natal eyaletinde yaşayan, ülkenin en büyük Afrikalı etnik grubudur (Mayer ve Boness, 2003). Zulu kültüründe spiritüel dünya büyük önem taşımaktadır (Mayer ve Viviers, 2016). Hellinger, Zulu kabilesine mensup bireylerin, ateş etrafinda toplanarak, sorunlarının çözümüne yönelik yaptıkları törenleri izlemiş, atalarının ruhları ile bağlantı kurmalarına şahitlik etmiştir. Onların aile yapılarına, çocukların ebeveynlerine sorgusuz saygılarına, ebeveynlerin çocukları üzerindeki doğal otoritelerine hayran olmuştur (Franke, 2017).

Hellinger 1969 yılında Almanya'ya geri dönmüş, bir süre yürüttüğü terapötik çalışmalarında, bu kabileden edindiği tecrübelerini kullanmıştır. 1970 yılında Viyana'ya giderek psikanaliz eğitimi alıp psikanalist olmuş ve Psikanaliz Birliği'nde ders vermeye başlamıştır. Derslerinin birinde Arthur Janov'un alışılmadık ve devrim niteliğindeki çalışmalarından bahsetmesiyle dernekte gözden düşmüştür (Franke, 2017). Hellinger, dernekten ayrilarak Amerika'ya gitmiş, Los Angeles'ta dokuz ay süreyle Janov ile "A ğlama Terapisi" olarak da bilinen "Primal Terapi (Primal Therapy)" çalışmıştır. Hellinger, yaşamının bu döneminde pek çok terapi modeli ile tanışmıştır. Özellikle Eric Berne'nin "Transaksiyonel Analiz (Transactional Analysis)"i Hellinger üzerinde büyük etki bırakmıştır. Uzun bir zaman grup çalışmalarında bu model ile çalışmalarını sürdüren Hellinger zaman içerisinde, bu modelin her zaman işe yaramadığını gözlemlemeye başlamıştır. Terapötik çalışmalarında, mevzuların bazen geçmişe kadar gittiğini ve geçmişte köklendiğini fark etmeye başlamıştır. Böylece zihninde yeni bir bakış açısı belirmeye başlamıştır: "Sistemik Çok Nesilli Yaklaşım (systemic multigenerational aspect)" $\ldots \quad \mathrm{Bu}$ yeni yaklaşımıyla çalışmalarını sürdürürken nesiller arası dengenin önemini dile getiren bir düşünür olan Ivan Boszormenyi-Nagy'den de çok etkilenmiştir. Milton Erikson'dan öğrendiği "hipnoterapi (hypnotherapy)" metodundan, hikâye anlatma yöntemini ve genellikle sözel mesajlara uymayan minimal sözsüz ipuçlarının ayrıntılı gözlemini seçip almıştır (Franke, 2017). Yöntemine entegre ettiği diğer önemli etkiler arasında Jacob L. Moreno'nun psikodramas1, NLP (Neuro Linguistic Programming) ve Virginia Satir'in aile rekonstrüksiyonu bulunmaktadır (Stones, 2006).

Hellinger'in Türkçe'ye çevrilmiş "Sevgi Düzenleri”, "Sevginin Saklı Simetrisi”, "Kabul Etmenin Özgürlüğü”, 
ve "Yardım Etmenin Düzenleri” isimli kitapları bulunmaktadır. Hellinger, 2019 yılında hayata gözlerini yummuştur.

\section{Aile Dizimi Nedir?}

Aile dizimi (family constellation) terimi ilk olarak Adler (1927) tarafindan aile sistemindeki her üyenin nişini (görevini) tanımlamak için bir yapı olarak kullanılmıştır. Adler, aile takımyıldızının ebeveynlerden, çocuklardan ve geniş aile üyelerinden oluştuğunu belirtmiştir. Almanca "Familien Aufstellung" adiyla 90'larda Almanya'da ortaya çıkmış olan "Aile Dizimi Terapisi (Family Constellation Therapy)" ise, ailenin nesiller boyunca, birbirlerine görünmez bir bağ ile bağl1 olduğu anlayışına dayanmaktadır. Aile bir bütün olarak bir ruha sahiptir (Stone, 2008). Bireyi, içine doğduğu ailenin şekillendirdiğini benimseyen bu anlayış, ailenin bir sistem oluşturduğunu ileri sürmektedir. Aile sistemindeki bir kişi kadersel olarak diğer bir aile üyesine bağlıdır. Ruhsal tekâmül sürecinde; ruhun bedenlendiği ailedeki her birey birbirini seçerek gelmişlerdir. Bu yolculukta, bir arada olan tüm aile üyelerinin birbirlerinden öğrenecekleri șeyler vardır. Hellinger, psikolojik rahatsızlıkların büyük -belki de çoğu- bir kısmına, kök ailede yaşanmış sorunların sebep olduğunu söylemektedir.

\section{Aile Diziminde Bazı Önemli Kavramlar}

Hellinger, Weber ve Beaumont (1998) ilişkilerimizde temel ihtiyaçlarımızın karmaşık şekillerde etkileşime girdiğinden ve ilişkilerimizi sınırlandırdığından söz eder: "bağ (bonding) kurmak için aidiyet ihtiyacı, sıra/düzen (order) için sosyal güvenlik ve öngörülebilirlik ihtiyac1, ahenk için verme ve alma arasındaki dengeyi (balance betwen giving and taking) sağlama ihtiyac1.

\section{Bağlar ve İliş̧ki}

İnsanlar, "özel (privately)" ve "profesyonel (professionally)" daima ilişki içinde yaşamaktadırlar ("The Original Hellinger", 2020). Birey eğer hayattaki görevlerini ve doğru yerini bulmak istiyorsa yaşamın temel ilkelerini entegre etmelidir. Hellinger bu ilkeleri "Sevgi Düzenleri (Love Orders)" olarak adlandırmıştır. Sevgi düzenleri, evrensel yaşam kurallarıdır ve hayatın her seviyesinde başarı için temeldir. Eğer sevgi düzenlerine saygı duyulursa, sevgi enerjisi aile içerisinde özgürce akabilmektedir.

Hellinger ve arkadaşları (1998) aile üyelerinin birbirlerine derin bir sevgi bağı ile bağlantılı olduğunu ileri sürmektedir. Aile üyeleri, aile üyelerinden birinin kaybının dengelenmesi, aile düzenine saygi, al-ver ve kazan-kaybet dengesi ve aidiyet hakkı açısından aile düzenini etkileyen bir aile bilinciyle birbirlerine bağlıdır (Mayer ve Viviers, 2016). Çocuk aileye doğduğunda, hemen bu sistemin bir parçası olur. Hayatta kalmak için aileden ihtiyaçlarını alır, bu sırada bu ailenin üyeleriyle nasıl birlikte yaşayabileceğini de öğrenir. Ailenin kurallarını kendi kuralları gibi içselleştirir. Ancak bunun ötesinde, bu sistem içinde çok daha yaygın olan derin bir bağ vardır. Hellinger bu üyeliğin boyutlarını araştırmış ve bunu tanımlamak için sıra/düzen "order" kelimesini kullanmıştır.

\section{Sıra/Düzen (Order)}

Hellinger aile sisteminde bir tane doğru sıranın olduğunu varsayar. Bu doğru sıra sisteme huzur ve stabillik verir ki bu da her aile üyesinin sistemden memnun oluşunu sağlar. Sıra bazı kurallarla belirlenir. Bu kronolojik bir sıradır. Hiyerarşi önemlidir, önce orada olan insanların daha sonra gelenlere göre önceliği vardır (Hellinger, 2001). Bu anlayış, önceki evlilikler veya nişanlıklar gibi ebeveynlerin sahip olabileceği önemli ilişkilerin bu şekilde kabul edilmesi gerektiğini ima eder. Düzen aynı zamanda nesiller arasındaki ayrılığa saygı duyulması gerektiği anlamına da gelir. Kardeşlerin "doğum sırası"nın (birth order) korunması gerekir. Adler (1930, 1932) tarafından psikoloji literatürüne kazandırılan "doğum sırası" terimi, bir çocuğun aileye girme sırasını ve çocuğun ebeveynleri ve kardeşleri ile ilgili olarak işgal ettiği konumu ifade eder (Gallagher ve Lima, 2020). Adler, doğum sırasının çocuğun kişiliği ve davranış kalıpları üzerinde etkisinin olduğunu öne sürer. Buna göre ilk doğan sonraki doğanlardan önceliklidir. $\mathrm{Bu}$ sıranın korunması gerekir. Ailede ne olursa olsun hiç kimse dışlanamaz ve hiçbir üye sistemdeki haklı konumunu reddedemez. Bir sıra bozulursa, aşağıdaki nesiller bunu telafi etme görevini üstlenecektir. Duygusal bozukluklar ve psikosomatik hastalıklar aile sırasındaki bozukluktan kaynaklanabilir. Eğer bu bağ fark edilirse, aile sırası onarılır, semptomun sebebi de geçersiz kılınır. Örneğin çocuk ebeveyn rollerini üstlenirse sırayı bozmuş olur, bu aile trajedilerine, ciddi kazalara ve intihara sebep olabilir. Ya da küçük çocuk sırayı bozup kendini büyük çocuk yerine koyarsa, bilinçsizce yaşamında başarısız olma dürtüsüyle tepkiler veriebilir, mutsuz olur ve sürekli talihsizlikten yakınabilir (Hellinger, 2001).

Sıra/düzen savaş, kadersel darbeler gibi dış güçler tarafından ya da ailedeki bir üyenin dişlanması ya da kınanması gibi faktörlerce bozulabilir. Hellinger, terapötik çalışmalarında dışlanmaya kimsenin toleransının olmadığını görmüştür. Eğer aile içinde şiddet, intihar, cinayet, düşük, ana baba rollerinde uygunsuzluk gibi bir sebeple sistemde bir bozulma veya aile suralamasında bir kopma olursa, bundan aile fertlerinin hepsi, hatta etkisinin derinliği oranında gelecek kuşaklar da etkilenmektedir. Ve bu dengenin bozulması nesiller boyu devam edebilmektedir.

\section{Alma-Verme Dengesi}

Ailedeki doğal sıra ebeveynin vermesi çocuğun alması şeklinde akış göstermektedir. Çocuk ebeveyninden yeterince iyi "al"abilirse, ilerleyebilir ve o da kendi çocuklarına yeterince "ver"ebilir. Ancak bazen çocuğun ebeveynlerine dikkat etmesi/ ebeveynleriyle ilgilenmesi gereken durumlar olabilmektedir. Çocuklar her ne kadar bunu -çoğunlukla- severek yapsa da; bu durum onlara büyük bir yük oluşturur. Bu yükün etkileri bağımlılık ve şiddetin olduğu ailelerde daha net görülebilmektedir. Çocuk bu yük ile çok erkenden büyüyüp olgunlaşmak zorunda kalabilmektedir. Eşlerden birinin her zaman "ver"ip karşılığında çok az "al"ması da sorundur, böylesi bir al-ver döngüsünde ilişkinin sürmesi zordur ("Family Constellation Ireland”, 2019).

\section{Sistemik Karmaşıklık (Systemic Entanglement)}

Sistemik karmaşıklık, bir kişinin farkında olmadan başka birinin kaderini üstlendiği ya da yaşamını o kişinin öyküsüne kaptırdığı anlamına gelmektedir (Hellinger, 
2001). Kişinin ailesinden ya da önceki nesillerden aldığ 1 borçları/yükleri ifade eder (Franke, 2017). Bu borçlar suçluluk, etik meseleler olabilir. Örneğin ailede dışlanan kişinin kaderi bilinçsiz bir biçimde sonraki üyeler tarafından yüklenilir. Kişi tam anlamıyla ne olduğunu bilmeden bir diğerinin kaderini tekrar eder (Hellinger ve Hövel, 1999). Burada unutulmamalıdır ki suçluluk ve liyakat, bu duyguları duyanlara aittir ve başkası tarafından üstlenilemez (Stones, 2006). Sevginin özgürce akması için bireyin bu karmaşadan çıkması sağlanmalıdır.

Hellinger, borçları/yükleri maksimum üç ile dört nesil öncesinde arar ve bundan daha geçmiş nesilleri dikkate almaz. Çünkü ona göre, geçmişin barış içinde bırakılabileceği bir nokta muhakkak olmalıdır. Hellinger, sistemik karmaşada üç temel dinamik gözlemlemiştir: özdeşim kurma (identification), takip (following) ve devralma (takeover).

Özdeşim Kurma (İdentification): Özdeşim kişinin kendi hayatını yaşamasını engelleyen olaylar ve duygular barındırır. Tıpkı halası, aynı annesi vb. ifadeler Bu kişi sistemden dışlanmış biri olabilir. Özdeşim ile bu dışlanmış ve acı çeken kişinin enerjisini muhafaza eder (Franke, 2017). Bu yol ile kişi artık tam anlamıyla kendisi değildir. Özdeşimin bir başka sonucu da, ilişkinin kesintiye uğramasıdır, çünkü sistemik bir karışıklık ve kesintiye uğramış bir erişim çabası; kişinin bir başkasına kalıc bir bağ kurma ve sürdürme isteğini ve/veya sürdürme yeteneğini etkiler. Çünkü kişi kendisine yabancıdır. Neyin yanlış olduğunu bulma çabaları kimlik doğrulanıp çözülmedikçe başarısız olacaktır. Ancak o zaman yeni, pozitif bir ilişki başlayabilir.

Takip Etme (Following): Eğer aile üyelerinden biri ölüröldürülürse ya da büyük bir talihsizlik yaşarsa, sonradan gelen çocuklar ya da kardeşler kendilerinin de bu talihsizliğe doğru gittiğine dair bir hassasiyet taşırlar.

Devralma (Taking Over): Ebeveynler eğer bir başkasını takip ediyorlarsa (talihsizliğe doğru), çocuklar bu noktada ebeveynlerine duydukları sadakatin etkisiyle devreye girer ve bu denge arayışını üstlenirler. Karmaşanın sözcükleri olan "seni takip ediyorum" yerini "senin gitmendense ben giderim daha iyi", "senin ăglr kaderinin önünde tevazu/alçakgönüllülük ile ben duruyorum, ben bir çocuk olabilirim ama sen benim ebeveynimsin" șeklindeki ifadelere bırakır (Stones, 2006). Benzer bir davranış, ebeveynlerin ayrıldığı ailelerde de görülebilir. Bir çocuk hastalanır, çalmaya başlar ya da okulda başarısız olur, $\mathrm{Bu}$ da her iki ebeveynin de dikkatlerini yüzeyde bir sorun gösteren bu "gösterge hastaya (index patient)" yönlendirmesine yol açar. Bununla birlikte, daha derin bir düzeyde, çocuk kendi iyiliği pahasına bile ailenin dayanışmasını sağlamaya isteklidir.

Dizimde öncelikle sistemik karmaşalar gün 1şığına çıkarılır. Bilinçsiz hareketler bilinçli zihne getirildiğinde, güçlerini kaybetmeye başlar ve çocuğun ruhunu olgunlaşması için özgür bırakır. Bu olgunlaşma, kör aşkın (blind love) güzelliğini olduğu kadar faydasızlı̆ını da açığa çıkarır. Olgunlaşma, kör sevginin alçakgönüllülük ve merhametle kabul edilmesini sağlar; genç ruhun başkalarının acılarını ortadan kaldırmak isteyen sevgisi, sevdiklerinin kaderini kabul etmeyi öğrenen ve onları kendi kaderlerine bırakan olgun bir sevgiye dönüşür (Stones, 2006).

\section{Kesintiye Uğramış Erişim Çabası (İnterrupted Reaching-Out Movement)}

Çocuğun duygusal olarak kendini çekmesini ifade eder. Anne veya baba duygusal olarak erişilemez durumdadır. Çocuğun "verme" eylemi ebeveynler tarafindan takdir edilmediğinde "örneğin anne ya da bana şimdiki ilişkinin farkında değildir" bu durum ebeveynlerin kendi sistemlerine dolanmış olmaları ile açıklanabilir. Kişi aileden birini takip ediyor olabilir. Sanki kişi, geriye doğru bağlıymışlar gibidir. $\mathrm{Bu}$ yüzden enerji şimdiki zamana akmaz, ya da sonraki nesillere (çocuğuna) akmaz. Kişi mevcut sistemdeki ilişkilerinde mevcut değildir yani orada değildir. Çocuk bu nedenle, ebeveynlerine her erişim isteğinde derin hayal kırıklığı yaşar ve nihayetinde kendini duygusal olarak geri çeker. $\mathrm{Bu}$, bir ebeveynin gerçekten kaybı olabileceği gibi, ebeveynden ayrılma veya duygusal yokluğun sonucu da olabilir (Franke, 2017). Çocuk, birincil sevgi (Hellinger "primary love" ya da "original love" olarak da adlandırmaktadır) nedeniyle ebeveynleri için her şeyi yapmaya gönüllüdür. Ancak çocuğun bu girişimleri ebeveyn tarafindan reddedilirse ya da onurlandırılmazsa bu sevgi acıya dönüşür. Hellinger çoğu duygusal acının temelinde kesintiye uğramış sevgiyi görmüştür. $\mathrm{Bu}$ acı çocuk için çok yoğun bir acıdır. Bu nedenle çocuk ebeveyne yaklaşmak istemez onlardan uzaklaşır. Daha fazla acı hissetmekten kendini korumak için tüm girişimleri de geri çevirir. Sistemdeki aksaklıklar işte böyle nesiller boyunca aktarılır.

\section{Duygular}

Duygular davranışların düzenlemesinde önemli olup; birey için pozitif duygular gerekli olduğu kadar negatif duygular da gereklidir (Duman, 2019). Hellinger üç tür duygu arasında ayrım yapmaktadır. Birincil (primary), ikincil (secondary) ve varsayılan (assumed) duygular olarak gruplandırdığı bu duyguları terapötik süreç için kriter olarak kullanmaktadır. Benzer bir gruplama duygu odaklı terapide de yapılmakta olup birincil duygular anahtar bir etmen olarak kabul edilirken, ikincil duygular genellikle savunma ve baş etme stratejileri olarak görülmektedir (Bridge, 2019; Johnson, 2004).

Birincil Duygular: Çocuğun ailesi için hissettiği aşk/sevgi her şeyin temelini oluşturur. Bu birincil sevgi ebeveyn ve çocuk arasındaki temeldir ve ilişkilerden, eylemlerden ve olaylardan etkilenmez. Bundan kaçınılamaz ve istesek de istemesek de etkisi vardır. Hellinger, yüzeye gelen güçlü duyguların neredeyse her zaman başka bir duyguyu, yani çocuğun annesi ve babası için "birincil sevgisi (primary love)"ni örtmek için kullanıldığını fark etmiştir. Kızgınlık, öfke, üzüntü ve umutsuzluk duygularının küçük bir çocuğun babaya veya anneye olan erişim çabasının kesintisinin neden olduğu "acı"yı gidermeye yaradığını anlamıştır.

Örneğin çocuk babasını ya da annesini kaybettiğinde "keder"i yaşamaz. Çünkü bu derin duyguyla başetmek için henüz gelişiminde yeterince yol kat etmemiştir. Çocuk bu duygu yerine "hiddet-öfke (rage)" hisseder. Ancak çocuk her iki ebeveynine de bağlı olduğu için onlara derin bir sadakati vardır. Bu nedenle, hiddet/öfke duygusu da kaygıyla yer değiştirir. Çocuk hiddetinden ve öfkenin ifade edilmemiş sonuçlarından korkar. Bu nedenle kaygı çocuğun yüzeyde algıladığı duygu olmaya devam eder. Kaygı yoluyla, çocuk ve daha sonra yetişkin, kederinin derin ve acı verici hisleriyle yüz yüze 
gelmekten kendini korur. Kişi için çözüm ebeveynlerine tekrar dönerek o dönemde yaşanmamış olan duyguların şu anda olmasına izin vermektir. Böylece kişideki blokaj çözülür.

İkincil Duygular birincil duygular yerine belirir. Çünkü birincil duygular durum için uygun değildir. Bu duygular danışanda, çaresiz veya güçsüz öfke veya dipsiz, derin bir umutsuzluk ve depresyon gibi zayıflık hissi bırakırlar. Bunlar, sevginin kesintiye uğramış uzanma hareketi bağlamında ortaya çıkan duygulardır. Çocuk sevdiği insanlara doğru hareket etmek yerine, "mesafesini korumayı tercih eder ve aşk yerine öfke, umutsuzluk ve üzüntü hisseder". Kısa terapinin gerekliliklerine bağlı olarak, Hellinger bu ikincil duyguların üzerinde durmaz, çünkü bunlar sorunun özünü oluşturmazlar. Sadece çözüm yolunda dururlar. Bu duyguların kesintiye uğramış sevgi olduğunu anlarsak, yüzeysel hislere saplanmayı, ancak sevginin orijinal hareketini yeniden kurmak için çalışabiliriz.

Varsayılan Duygular; ise sistemik karışıklıkların net bir resmini sunar. Özdeşim kurmada, "duygular bilmeden başkasından alınır ve olduğu gibi durumla ilgisi olmayan bir başkasına yöneltilir/yönlendirilir" (Hellinger, 2001). $\mathrm{Bu}$ şekilde, sistemik dengesizlik, önceki nesillerden çözülmemiş ilişkilerin alınarak mevcut ilişkilere aktarılmasına neden olur. Aslında tüm bunlar sisteme hizmet etmek için aktarılır. Ancak yine de bir denge oluşmaz ve duygular, bu ya da başka bir biçimde gelecek nesillere aktarilır.

\section{Aile Diziminde Ne Yapılır?}

Aile diziminde sıranın bozulması, sistemik karmaşa ve kesintiye uğramış erişim/yönelim çabaları sebebiyle ortaya çıkan sorunlar ele alınır. Hellinger, geliştirdiği bu modelde danışanı ailesiyle içsel dünyada barıştırarak; aile sistemi içindeki mevcut yerini göstererek, sistemin çökmüş ve bozulmuş taraflarını onarmaya çalışır. Ailesiyle "ruhunun derinliklerinde buluşturulacak" olan bireyin yaşı, yaşadığ $\breve{g}$ mekan, zaman ve ortam, mensubu olduğu ailenin diğer üyelerinin hayatta olup olmaması mühim değildir. Bu süreç danışanın kendi iç dünyasında cereyan etmektedir.

Aile dizimine gelen kişinin davranışı ve ifadeleri derinlemesine oturmuş bir dizi "görünmez sadakati" temsil eder. $\mathrm{Bu}$ yapıdaki değişiklikler davranış, düşünme ve buna karşıllk duygularda değişikliklere yol açar. Dizim sırasında dışlanmış kişiye ailedeki yeri (görsel olarak sandalye) geri verilir. Aile sistemindeki bilinçsiz/bilinçdışı karmaşık bağları açığa çıkarılır. Kişiye ailede özdeşleştiği kişinin farkına varması ve bu özdeşimi çözüme kavuşturması için firsat sunulur. O kişinin ayrı bir birey olduğunu kişi farkediceye kadar çalışma tekrar ettirilir. Kesintiye uğramış erişim çabası hususunda vekillerle temsil edilen baba veya anne ile yeni bir ilişkinin ortaya çıkmasına izin verilir. Önceki nesillerle yeni duygusal bağlar kurmak, dengeyi bulmak ya da karışık bağlara çözüm sağlamak için müdahalede bulunulur/araci olunur.

Aile dizimine giren kişi için diğer aile üyeleriyle ilişkiler yeni baştan, tıpk1 yeni doğan bir bebeğin saflığı ve sıcaklığıyla kurgulanır. Kişi böylece derin bir içsel huzura kavuşur. Korkular, zayıflıklar, özgüven sorunları, öfke, kin, soğukluk ve katılık gibi duygular zamanla yerini kendine güvene, güçlü duruşa ve kararlılığa; sıcak, yumuşak ve uyumlu davranışlara terk eder.

\section{Aile Dizimi Uygulaması}

Aile dizimi uygulaması, aileler, çiftler, çocuklar ve hatta işyerleri, hastalıklar, şirketler için yapılabilmektedir ("The Original Hellinger", 2020). Aile dizimi, grup terapisinde bir işleyiş olarak düşünülebilir (Franke, 2017). Psikodrama ile pek çok benzer yönleri olmasının tersine aile diziminde psikodramada olduğu gibi belirli bir durum ya da davranış sergilenmez. Dizime gelen danışan, seansta kendi ailesinin içsel bir resmini oluşturmaktadır (Franke, 2017). Aile diziminde koltuklar/sandalyeler kullanılmakta olup; dizim, bireysel dizim ya da grup dizimi şeklinde gerçekleştirilebilmektedir.

Uygulama öncesinde, terapistin verdiği ev ödevleri aracılığıyla, birey soyağacını araştırmaktadır. Bireysel dizim sorunlarını grupla paylaşmaya istekli olmayan bireyler için daha uygundur. $\mathrm{Bu}$ çalışma yönteminde danışanın ailesi hakkında verdiği bilgiler doğrultusunda 'anne', 'baba', 'teyze', 'ölen kardeş' veya 'anneanne' gibi bireyleri temsil eden koltuklar/sandalyeler seçilmektedir. Bireysel dizimde aile bireylerinin yaşadıkları içsel sıkıntılar koltukların temsil ettiği kişiler ve bireyin bu koltukları nasıl dizdiği ile dile getirilmektedir. Örneğin; babayı temsil eden koltuk diğer koltukların dışında, uzak bir yere yerleştirildiğinde, bu bireyin babasıyla ciddi bir sorun yaşadığına işaret edebilmektedir. Vekilleri temsil eden koltuklara terapist oturabileceği gibi, bloklar, yastıklar da temsil için kullanılabilmektedir (Schober-Howorka, 2012). Danışandan aile bireylerinin yerine geçmesi, onları temsil eden koltuğa oturması, neler hissettiğini aktarması da istenilmektedir. $\mathrm{Bu}$ süreçteki en kıymetli soru "ne hissediyorsun?" sorusudur. Kişinin burada sarf ettiği kelimeler, hastalığı/problemi çözmekte, o insanların neler yaşadıklarını fark etmesine, kalbinin derinliklerinde acı ve yanma duygusu oluşmasına yol açmaktadır. Grup diziminde ise danışan bu bireyleri temsil edeceğini düşündüğü kişileri grup içerisinden seçmektedir (Franke, 2017). Danışan, seçtiği kişilerin ifadelerini dışarıdan dinlemektedir (Franke, 2017). Grup diziminin bir avantaj1 vekilleri ve vekillerin birbirleriyle olan ilişkilerini doğrudan deneyimleme olanağıdır (Schober-Howorka, 2012). Danışan ihtiyaç duyduğunda bu kişilerin yanına gidebilmekte, sarılabilmekte ve konuşabilmektedir.

Aile diziminin geleneksel terapilerden farkı, sorulara kısa yanıtlar verilmesi ve telkinde bulunulmamasıdır. Seans sırasında enerji akışına izin verilmektedir. En nihayetinde dizim, hiç kimsenin değişmesini beklemeden, "kabul ederek", kişinin ruhsal özgürlüğe doğru yol almasını sağlamaktadır: "Seni artık olduğun gibi kabul ediyorum!"

\section{Sonuç}

İnsanların diğerleriyle kurduğu ilişkiler, son derecede dayanıklı olabilmektedir. Bu ilişkiler sadece şuanda var olan insanlarla değil, geçmişte ve gelecekteki insanlarla da kurulmuş olabilmektedir. Şu kabul edilmelidir ki geçmiş değiştirilemez. Ve fakat bireyin geçmişi yorumlama şekli değiştirilebilir. Bireyin diğer aile üyeleri ile ilişkileri modifiye edilebilir. $\mathrm{Bu}$ yeniden şekillendirilmiş ilişkiler de kişinin gelecek hayatı üzerinde daha zayıf etki uygulayacaktır (Toman, 1993). Aile diziminde düşüncelerin, algıların ve duyguların 
somut temsili ve dışsallaştırılması, dışsal algının bir görüntüsünü oluşturmaktadır. $\mathrm{Bu}$ sorunlu görüntüye oturum sirasinda müdahale edilerek, sorunlu durumun imaj1 "daha iyi" ve "iyileştirici" bir görüntü ile değiştirilmektedir. Aynı zamanda, kişide kendi sistemine ait olan ve daha geniş bir bağlamda, eldeki dünyaya ait derin bir anlayış da oluşmaktadır.

Terapilerde sistemik görüşlerin analizi ve kullanımı gittikçe önem kazanmaktadır. Aile diziminin kullanımıyla, aile içindeki sistemik yapılara erişim sağlandığ 1 görünmektedir. Aile dizimini kullanarak tedavinin başlıca avantajları, danışanın içinde yaşadığ sistemin yapısal bağlantıları ve çalışmanın getirdiği büyük etki hakkında kısa sürede net bir resim elde etmesidir. Bu nedenle, bu yöntemin pratik olarak bilimsel araştırmalarla sağlam bir temelin sağlanması arzu edilebilir.

Bugün, pek çok terapist, hem aile hem de bireysel problemlerle başa çıkmak için aile dizimi yöntemini başlı başına veya alternatif bir terapi yöntemi olarak kullanmaktadır. Bu çalışmanın psikoterapi alanındaki ve özellikle aile diziminin kullanıldığı alanlardaki çalışmalara katkı sağlaması hedeflenmektedir. Aile dizimi terapisi ile diğer aile terapi modellerinin karşılaştırıldığı, aile dizimi terapinin yararlılığının incelendiği gelecek çalışmalara ihtiyaç vardır.

\section{Kaynaklar}

Adler, A. (1927). Individual psychology. The Journal of Abnormal and Social Psychology, 22(2), 116-22. https://doi.org/10.1037/h0072190

Adler, A. (1930). The education of children. New York, NY: Greenburg.

Adler, A. (1932). What life should mean to you. Boston, MA: Little, Brown.

Bowlby, J. (1951). Maternal care and mental health. London: World Health Organization.

Bridge, E. N. (2019). Emotionally focused couple therapy: A couple's struggle with infidelity. International Journal of AfroEurasian Research (IJAR), 4(8), 155-66.

Duman, N. (2019). Mentalizasyon ve mentalizasyonun psikopatoloji, duygudurum düzenleme, saldırganlık ve şiddet ilişkisi üzerine bir derleme. PESA Uluslararasl Sosyal Araştırmalar Dergisi, $\quad 5(2), \quad 200-8$. https://doi.org/10.25272/j2149-8385.2019.5.2.12

Family Constellations. (2016). Erișim tarihi: 27.06.2020, Erişim adresi: https://www.goodtherapy.org/learnabouttherapy/types/family-constellations

Family Constellation Ireland. (2019). Erișim tarihi: 27.06.2020, Erişim adresi: https://www.familyconstellationsireland.com/orders-of-love

Franke, U. (2017). The river never looks back historical and practical foundations of Bert Hellinger's family constellations. Ebook. Carl-Auer-Systeme Verlag: Heidelberg.

Gallagher, R., \& Lima, C. N. L. (2020). Birth order and family constellation. The Encyclopedia of Child and Adolescent Development, 1-13. doi:10.1002/9781119171492.wecad216

Hellinger, B. (1995). Familien-Stellen mit Kranken. Handbook accompanying 10-hour live video edition of a course for patients and their psychotherapists and physicians. Heidelberg (CarlAuer-Systeme).

Hellinger, B. (2001). Love's own truths. Bonding and balancing in close relationships. Phoenix, AZ:Zeig, Tucker and Theisen.

Hellinger, B., \& Hövel, G. (1999). Acknowledging what is: Conversations with Bert Hellinger. Phoenix, AZ: Zeig, Tucker and Co., Inc.
Hellinger, B., Weber, G., \& Beaumont, H. (1998). Love's hidden symmetry: What makes love work in relationships? Phoenix, AZ: Zeig, Tucker and Theisen.

Johnson, S. M. (2004). The practice of emotionally focused couple therapy: Creating connection. New York, NY: Brunner Routledge.

Laosa, L. M., \& Sigel, I. E. (1982). Families as learning environments for children. New York and London: Plenum Press.

Mackay, N. (2012). Between the lines: Healing the individual \& ancestral soul with family constellation. Winchestar UK: OBooks.

Mayer, C.-H., \& Boness, C. M. (2003). Südafrikanische Kulturstandards. Handlungsrelevantes Wissen für Fach- und Führungskräfte. Africa Spectrum, 38: 173-196.

Mayer, C.-H., \& Viviers, R. (2016). Constellation work and Zulu culture: Theoretical reflections on therapeutic and cultural concepts. Journal of Sociology and Social Anthropology, 7(2), $101-10$.

Schober-Howorka, J. (2012). Family constellation and past lives with newly developed methods and resolution statements. 5th edition. Germany: Schirner Verlag.

Stone, B. (2008). Invisible roots: How healing past life trauma can liberate your present. Santa Rosa, CA: Energy Psychology Press.

Stones, B. (2006). A brief history of Bert Hellinger's family constellations. Self \& Society, 33(4), 5-9.

The Original Hellinger Family Constellation. (2020). Erişim tarihi: 29 Mays 2020, Erisim adresi: https://www.hellinger.com/en/home/family-constellation/

Toman, W. (1961). Family constellation:Theory and practice of a psychological game. New York: Springer.

Toman, W. (1993). Family constellation: Its effects on personality and social behavior, 4th Edition. New York:Springer Publishing Company. 